\title{
Article 28. Secretariat
}

1. The Secretariat established by Article 24 of the Convention shall serve as the secretariat to this Protocol.

2. Article 24, paragraph 1, of the Convention on the functions of the Secretariat shall apply, mutatis mutandis, to this Protocol.

3. To the extent that they are distinct, the costs of the secretariat services for this Protocol shall be met by the Parties hereto. The Conference of the Parties serving as the meeting of the Parties to this Protocol shall, at its first meeting, decide on the necessary budgetary arrangements to this end.

Article 28, which mirrors the corresponding provision of the Biosafety Protocol, ${ }^{1}$ makes provision for the Secretariat of the Protocol, which is responsible to administer the treaty and to act as day-to-day contact point for its Parties, international organizations and others. The Secretariat also prepares documentation for meetings of the governing and subsidiary bodies of the Protocol, and is in charge of organizing and servicing their meetings. It further plays an important role in the functioning of the ABs Clearinghouse. ${ }^{2}$ The Secretariat's tasks will also likely include the preparation of reports on the execution of its functions under the Protocol for consideration by the COP/ MOP, and coordination with other relevant international bodies. ${ }^{3}$ Upon the Protocol's entry into force, the COP/MOP will likely assign additional specific functions and tasks to the Secretariat. ${ }^{4}$

The свD Secretariat will also perform the functions of the Secretarirat for the Protocol, as is customary in multilateral environmental agreements for cost-efficiency reasons. Thus, Article 28 also addresses the separation of costs incurred by the Secretariat for its services for the Protocol rather than for the

1 Biosafety Protocol Article 31.

2 See this commentary on Article 14, section 3.

3 свD Article 24. See Glowka, Burhenne-Guilmin and Synge, Guide to the Convention on Biological Diversity, op. cit., 114. See also this commentary on Article 4.

4 Greiber et al., Explanatory Guide, op. cit., 239-240. For a similar discussion in relation to the Biosafety Protocol, see Mackenzie et al., Explanatory Guide to the Cartagena Protocol, op. cit., 187-188. 
СвD. As in the context of the Cartagena Protocol, this may have impacts on the ratification of the Protocol by developing countries: if developing countries are the first to ratify the Protocol, ${ }^{5}$ they will have to bear the costs incurred by the Secretariat in servicing the Protocol, which can constitute a significant financial burden for these countries. ${ }^{6}$

$5 \quad$ And indeed at the time of writing, only one developed country Party (Norway) has ratified the Protocol: see this commentary on Article 1, fn. 63.

6 For a similar discussion in relation to the Biosafety Protocol, see Mackenzie et al., Explanatory Guide to the Cartagena Protocol, op. cit., 188. Note however that, notwithstanding ratification, all СвD Parties have obligations under the third objective of the Convention as operationalized in СвD Articles 1, 8(j), 15 and other related provisions. 